Diminished salivary epidermal growth factor secretion : a link between Sjogren's syndrome and autoimmune gastritis?

Koskenpato, K.

2016-03-03

Koskenpato , K, Ainola , M , Przybyla , B , Kouri , V-P , Virkki , L, Koskenpato , J , Ristimaki , A \& Konttinen , Y T 2016 , ' Diminished salivary epidermal growth factor secretion : a link between Sjogren's syndrome and autoimmune gastritis? ' , Scandinavian Journal of Rheumatology, vol. 45 , no. 2 , pp. 118-121 . https://doi.org/10.3109/03009742.2015.1072243

http://hdl.handle.net/10138/161147

https://doi.org/10.3109/03009742.2015.1072243

publishedVersion

Downloaded from Helda, University of Helsinki institutional repository.

This is an electronic reprint of the original article.

This reprint may differ from the original in pagination and typographic detail.

Please cite the original version. 


\title{
Diminished salivary epidermal growth factor secretion: a link between Sjögren's syndrome and autoimmune gastritis?
}

\author{
K Koskenpato, M Ainola, B Przybyla, V-P Kouri, L Virkki, J Koskenpato, A \\ Ristimäki \& YT Konttinen
}

To cite this article: K Koskenpato, M Ainola, B Przybyla, V-P Kouri, L Virkki, J Koskenpato, A Ristimäki \& YT Konttinen (2016) Diminished salivary epidermal growth factor secretion: a link between Sjögren's syndrome and autoimmune gastritis?, Scandinavian Journal of Rheumatology, 45:2, 118-121, DOI: 10.3109/03009742.2015.1072243

To link to this article: http://dx.doi.org/10.3109/03009742.2015.1072243

曲 Published online: 23 Sep 2015.

Submit your article to this journal 2

Џ Article views: 76

Q View related articles

View Crossmark data $\nearrow$ 


\title{
Diminished salivary epidermal growth factor secretion: a link between Sjögren's syndrome and autoimmune gastritis?
}

\author{
K Koskenpato ${ }^{1,2}$, M Ainola', B Przybyla ${ }^{1}$, V-P Kouri ${ }^{1}$, L Virkki ${ }^{1}$, J Koskenpato ${ }^{3,4}$, A Ristimäki ${ }^{4,5}$, YT Konttinen ${ }^{1,4,6 *}$ \\ Departments of ${ }^{1}$ Medicine, ${ }^{2}$ Anatomy, and ${ }^{3}$ Gastroenterology, University of Helsinki, ${ }^{4}$ Helsinki University Central Hospital, \\ ${ }^{5}$ Department of Pathology, University of Helsinki, and ${ }^{6}$ ORTON Orthopaedic Hospital, ORTON Foundation, Helsinki, Finland
}

Objectives: Healthy human labial salivary glands produce epidermal growth factor (EGF). In Sjögren's syndrome (SS), EGF staining is diminished. SS is also associated with chronic autoimmune corpus gastritis. We therefore hypothesized that EGF secretion would be diminished in SS and that this could affect gastric target cells.

Methods: Salivary EGF secretion in SS was compared to that in healthy controls using an enzyme-linked immunosorbent assay (ELISA). EGF receptor (EGFR) immunoreactive cells in the gastric corpus of healthy human subjects were analysed using immunostaining.

Results: Salivary secretion of EGF was diminished in SS patients (232.4, range 52.6-618.4, vs. 756.6, range 105.3$1631.6 \mathrm{pg} / \mathrm{min}, \mathrm{p}=0.002$ ). Proton-pump positive parietal cells were mostly EGFR immunoreactive whereas very few pepsinogen I (PGI)-positive cells were EGFR positive.

Conclusions: As EGF is relatively acid resistant, salivary gland-derived EGF might participate in an exo/endocrine mode of parietal cell maintenance in the gastric corpus. Deficiency of salivary gland-derived EGF in SS patients may cause impairment of gastric parietal cells resulting in exposure of immunogenic cryptic antigens and loss of immunological self-tolerance.

Epidermal growth factor (EGF) is found in many human secretions, including plasma, urine, and gastric juice, but particularly in saliva $(1,2)$. EGF binding to the EGF receptor (EGFR) on cell surfaces regulates epithelial cell proliferation, adhesion/migration, and survival. EGF has been shown to protect gastric mucosa from various intraluminal injurious factors, such as gastric acid and pepsin $(3,4)$. Of interest, no EGF mRNA or protein has been found in healthy gastric tissues $(5,6)$. This implies that EGF found in gastric juice originates from other tissues, possibly from salivary glands. The concentration of EGF in saliva is $\sim 6-7$-fold higher than in gastric juice (2) and more than 50-fold higher than in plasma (1), suggesting production of EGF in saliva 'for export'.

We have previously described chronic autoimmune corpus gastritis in patients with Sjögren's syndrome (SS) (7). This finding was later confirmed in another study (8). Chronic autoimmune gastritis is restricted to the gastric body. This agrees with a relatively high prevalence of

$\overline{\text { *Deceased }} 10$ December 2014.

Mari Ainola, Clinicum, Department of Medicine, BMH1, Haartmaninkatu 8, FI-00029 HUS, Helsinki, Finland.

E-mail: mari.ainola@helsinki.fi

Accepted 9 July 2015 parietal cell-specific autoantibodies in SS (9), whose main target is the gastric $\mathrm{H}^{+} / \mathrm{K}^{+}$ATPase (10).

Healthy human salivary glands stain for EGF but staining is diminished in patients with SS (11). We therefore hypothesized that, in SS, a diminished salivary flow would lead to a diminished and disturbed EGF secretion. Because of the association between SS and autoimmune gastritis, we further hypothesized that parietal cells located in the gastric corpus are potential target cells of salivary EGF.

\section{Method}

Patients and samples

Stimulated saliva was collected from 28 females diagnosed with primary SS (age range 38-78; median 55.5 years) and from 12 healthy, female controls (age range 22-55; median 52.0 years). The age difference between the groups was significant $(\mathrm{p}=0.01)$. Patients with primary SS fulfilled the American-European criteria (12). Healthy controls were employees of Biomedicum Helsinki and were in general good health (self-reported). Stimulated whole saliva samples were collected by chewing a piece of hard paraffin for $5 \mathrm{~min}$, the samples centrifuged, and cell-free supernatants were stored at $-70^{\circ} \mathrm{C}$ with proteinase inhibitors $(1: 25$, Roche, 
Basel, Switzerland). The total protein content was measured using the Bradford assay.

Multiple gastric biopsies were obtained from seven patients (age range 38-83; median 63.0 years) undergoing diagnostic gastroscopy without any abnormality in clinical examination and with normal findings in the histological evaluation of the biopses. Samples were fixed in 10\% buffered formaldehyde and embedded in paraffin.

The ethics committee of the Hospital District of Helsinki and Uusimaa approved the study (Dnr 19/E5/03) and the use of earlier collected gastric mucosal biopsies for this study (Dnr 44/13/03/01/2013).\#\#

\section{EGF enzyme-linked immunosorbent assay (ELISA)}

EGF concentrations in whole mixed saliva were measured using an ELISA (DEG00, R\&D, Minneapolis, MN, USA) according to the manufacturer's instructions. Samples were diluted 1:15 and tested in duplicate.

\section{Double immunohistochemical staining}

Four-micrometre-thick sections were stained using a fully automated Leica Bond-Max immunostainer (Leica Microsystems, Wetzlar, Germany). Double immunostaining was performed in a consecutive manner using two detection systems: horseradish peroxidase (HRP)-based Bond Polymer Refine (DS9800) and alkaline phosphate (AP)-based Bond Polymer Refine Red (DS9390). Antigens were retrieved in Epitope Retriaval solution 2 (Leica Microsystems) for $20 \mathrm{~min}$. The slides were incubated with primary antibodies for $30 \mathrm{~min}$. The following primary antibodies were used: mouse anti-human $\mathrm{H}^{+} / \mathrm{K}^{+}$ATPase $\beta$-subunit $\mathrm{IgG}_{1}(0.125 \mu \mathrm{g} / \mathrm{mL}$, Clone 2B6, Fitzgerald, MA, USA; $\mathrm{n}=3$ ), pepsinogen I (PGI) $\mathrm{IgG}_{1}(0.05 \mu \mathrm{g} / \mathrm{mL}$, Clone 4C6.1, Biohit Oyj, Helsinki, Finland; $n=6$ ), and rabbit anti-human EGFR IgG (1:100, Epitomics, Burlingame, CA, USA). Control non-immune rabbit IgG and mouse $\mathrm{IgG}_{1}$ were used at the same concentrations as the primary antibodies.

\section{Double immunofluorescence staining}

Antigens were retrieved in $10 \mathrm{mM}$ citrate buffer with $0.05 \%$ Triton X, pH 6.0, using a MicroMED microwave oven for $24 \mathrm{~min}$ at $+98^{\circ} \mathrm{C}$ (Milestone $\mathrm{Srl}$, Sorisole, Italy). Samples were blocked in $10 \%$ normal goat serum for $1 \mathrm{~h}$ and incubated with $0.5 \mu \mathrm{g} / \mathrm{mL}$ mouse anti-human $\mathrm{H}^{+} / \mathrm{K}^{+}$ATPase $\beta$-subunit and with 1:50 diluted rabbit anti-human EGFR overnight at $+4^{\circ} \mathrm{C}$. Secondary Alexa Fluor 488-conjugated goat antimouse IgG and Alexa Fluor 568-conjugated goat antirabbit IgG (Molecular Probes, Leiden, The Netherlands) were applied for $1 \mathrm{~h}$ at room temperature. Nuclei were counterstained with 4',6-diamidino-2-phenylindole
(DAPI). Negative staining controls were as described earlier.

\section{Statistical analysis}

The differences between groups were investigated with the Mann-Whitney U-test using IBM SPSS version 21. p-values $<0.05$ were considered statistically significant.

\section{Results}

EGF in saliva

Salivary secretion was significantly diminished in SS patients (median $0.67 \mathrm{~mL} / \mathrm{min}$, range $0.06-3.00 \mathrm{~mL} /$ min) compared to controls (median $1.75 \mathrm{~mL} / \mathrm{min}$, range $0.90-2.70 \mathrm{~mL} / \mathrm{min}$ ). The protein concentration $(\mathrm{w} / \mathrm{v})$ of whole mixed saliva was significantly higher in SS (median $0.86 \mathrm{mg} / \mathrm{mL}$, range $0.40-3.54 \mathrm{mg} / \mathrm{mL}$ ) than in controls (median $0.68 \mathrm{mg} / \mathrm{mL}$, range 0.37 $1.21 \mathrm{mg} / \mathrm{mL})$ but the protein secretion $(\mathrm{mg} / \mathrm{min})$ was significantly lower in SS (median $0.66 \mathrm{mg} / \mathrm{min}$, range $0.05-2.36 \mathrm{pg} / \mathrm{min}$ ) than in controls (median $1.09 \mathrm{mg} /$ min, range $0.40-2.13 \mathrm{mg} / \mathrm{min}$ ).

EGF concentration (w/v) in SS (median $273.6 \mathrm{pg} / \mathrm{mL}$, range $57.45-2074.5 \mathrm{pg} / \mathrm{mL}$ ) was not significantly different from controls (median $381.2 \mathrm{pg} / \mathrm{mL}$, range 88.5$673.2 \mathrm{pg} / \mathrm{mL}$ ). There was also no significant difference in EGF concentration per mg salivary protein between SS (median $328.1 \mathrm{pg} / \mathrm{mg}$, range $91.9-4943.4 \mathrm{pg} / \mathrm{mg}$ ) and controls (median $598.6 \mathrm{pg} / \mathrm{mg}$, range 111.9$1082.6 \mathrm{pg} / \mathrm{mL}$ ). EGF secretion was significantly lower $(\mathrm{p}=0.002)$ in SS (median $232.4 \mathrm{pg} / \mathrm{min}$, range 52.6$618.4 \mathrm{pg} / \mathrm{min}$ ) than in controls (median $756.6 \mathrm{pg} / \mathrm{min}$, range 105.3-1631.6 pg/min) (Figure 1).

In SS patients, EGF secretion was not significantly correlated with total protein secretion $(\mathrm{r}=0.19$;

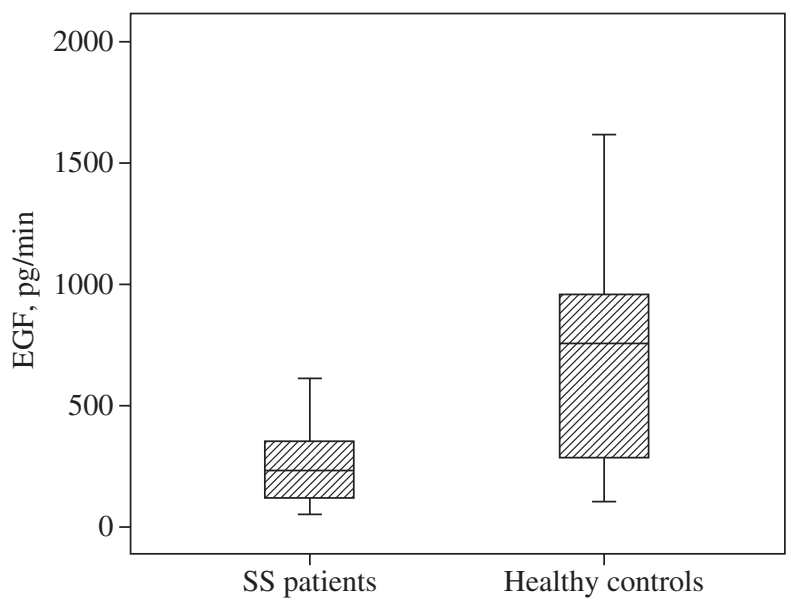

Figure 1. Box plot showing epidermal growth factor (EGF) secretion (pg/min) in patients with Sjögren's syndrome (SS) and healthy controls. 

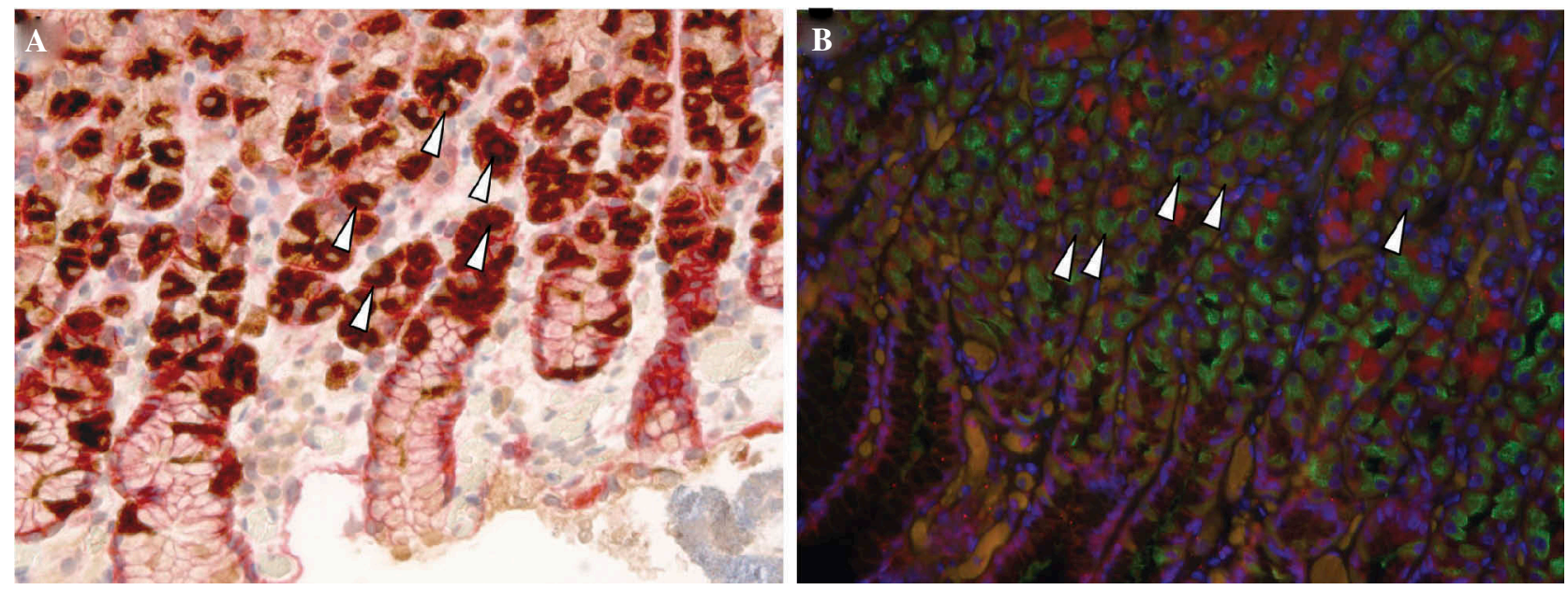

Figure 2. (A) Immunohistochemical staining showing $\mathrm{H}+\mathrm{K}+\mathrm{ATPase}$ immunoreactive parietal cells (brown) and epidermal growth factor receptor (EGFR, red). Some double-positive cells have been marked with arrowheads. The H+/K+ ATPase negative cells are also EGFR negative. (B) Double immunofluorescence staining showing $\mathrm{H}+\mathrm{K}+$ ATPase immunoreactive parietal cells (green) and EGFR (red). Some double-positive cells have been marked with arrowheads. Original magnification $\times 200$.

$\mathrm{p}=0.33)$ or with age $(\mathrm{r}=-0.167 ; \mathrm{p}=0.395)$, while in healthy controls there was a tendency for correlation of EGF secretion with total protein concentration $(\mathrm{r}=0.435 ; \mathrm{p}=0.157)$ and with age $(\mathrm{r}=0.436$; $\mathrm{p}=0.156)$.

Double staining of a parietal cell marker and EGFR

Immunohistochemical double staining of $\mathrm{H}^{+} / \mathrm{K}^{+}$ ATPase and EGFR disclosed an overlapping staining pattern. Most $\mathrm{H}^{+} / \mathrm{K}^{+}$ATPase immunoreactive parietal cells were also EGFR immunoreactive and EGFR staining was stronger at the basolateral plasma membrane (Figure 2A). Immunofluorescence supported these findings by showing similar results to EGFR immunoreactivity surrounding $\mathrm{H}^{+} / \mathrm{K}^{+}$ATPase immunoreactive parietal cells (Figure 2B).

\section{Double staining of a chief cell marker and EGFR}

Immunohistochemical double staining of PGI and EGFR revealed that most PGI immunoreactive cells were EGFR negative (Figure 3A). This double staining also revealed that many PGI negative (parietal) cells were EGFR immunoreactive, in particular at the basolateral plasma membrane (Figure 3A). Very few, weakly PGI positive (chief) cells were found to be EGFR positive (Figure 3B).
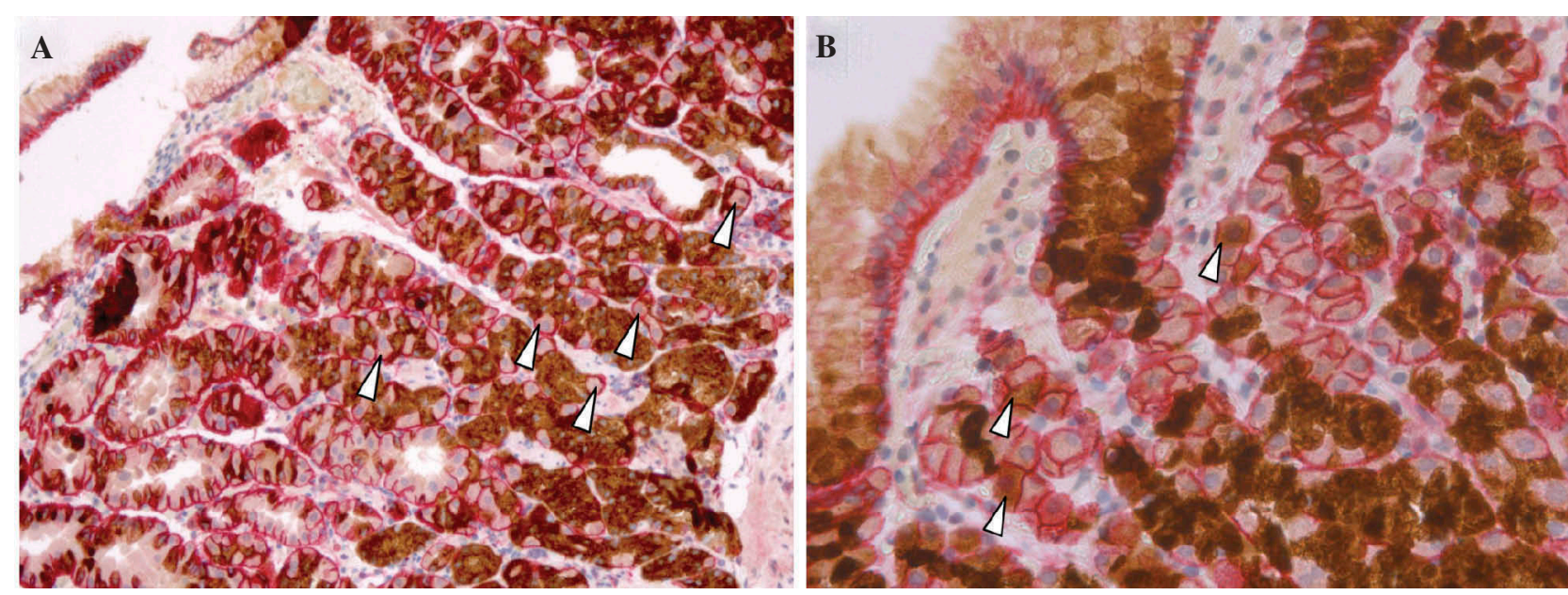

Figure 3. Immunohistochemical staining showing (A) pepsinogen I (PGI) immunoreactive chief cells (brown) and epidermal growth factor receptor (EGFR, red). Some double-positive cells have been marked with arrowheads. PGI negative cells are EGFR immunoreactive. Original magnification $\times 100$. (B) PGI immunoreactive chief cells (brown) and EGFR (red). Arrowheads point at some cells that are weakly stained for PGI and that are EGFR immunoreactive. Original magnification $\times 200$. 


\section{Discussion}

Sjögren's syndrome is an autoimmune epithelitis characterized by dry eyes (keratoconjunctivitis sicca) and dry mouth (xerostomia). The presence of focal lymphoplasmacytoid sialadenitis and/or SSA/Ro or SSB/La autoantibodies is required for diagnosis (12). Diminished production of saliva in SS may lead to diminished secretion of salivary gland-derived proteins and also impair the quality of saliva. In this study we show that salivary EGF secretion is diminished in SS, a result that is compatible with earlier findings $(11,13)$. The absence of any correlation between EGF and total protein secretion indicates that the decline in EGF in SS is not just a consequence of diminished overall protein secretion. Salivary EGF secretion is shown to increase with age (14), a finding that is confirmed by the results in our control group. Therefore, a difference in age between SS patients and the controls in our study cannot explain the diminished EGF secretion in SS. The correlation between age and EGF secretion is lost in SS, which may indicate disease progression as a determining factor.

$\mathrm{H}^{+} / \mathrm{K}^{+}$ATPase is a marker for parietal cells, which produce gastric acid, whereas PGI is a marker for chief cells. $\mathrm{H}^{+} / \mathrm{K}^{+}$ATPase/EGFR double staining results suggest that most parietal cells express EGFR and that most of the proton pump-negative cells, probably chief cells, are EGFR negative. In the PGI/EGFR double staining, most of the PGI negative cells, probably parietal cells, were EGFR immunoreactive. However, some weakly PGI immunoreactive cells were also EGFR positive. The reciprocal staining pattern in these two double staining experiments clearly establishes the parietal cells as EGFR positive cells and as a potential target for salivary EGF. The labelled polymer method used in this study bypasses the potential pitfalls such as immunologically non-specific labelling of parietal cells due to avidin-lectin (6) and streptavidin-RGD integrin (3) interactions. Although an exocrine and intraluminal mode of action has been suggested for salivary EGF (3), EGFR staining in this study showed more prominent basolateral than apical parietal localization of EGFR positive cell membranes.

We speculated that, in SS, the decrease in salivary EGF production and transient parietal cell action may lead to premature and abnormal apoptosis of the mature acid-producing, non-dividing, and migrating parietal cells resulting in a display of cryptic and immunogenic antigenic determinants. Proton pump-directed immune reactivity is pathogenic in arious experimental autoimmune gastritis models (15). Similarly, lack of central tolerance in autoimmune polyendocrinopathy type 1 or loss of peripheral tolerance in SS might play a role in autoimmune gastritis. In this study we propose a mechanism underlying the autoimmune gastritis in SS; however, additional studies in gastric tissue of SS patients are needed to support this hypothesis. In conclusion, diminished EGF secretion for export might form a link explaining the association observed between autoimmune corpus gastritis and SS.

\section{Acknowledgements}

This study was supported by grants from the Academy of Finland, Helsinki University Central Hospital, the Sigrid Jusélius Foundation, ORTON Orthopaedic Hospital of the Orton Foundation, the Jane and Aatos Erkko Foundation, the Finnish Cultural Foundation, the Orion Foundation, and the Rheumatology Research Foundation.

\section{References}

1. Konturek SJ, Bielanski W, Konturek JW, Oleksy J, Yamazaki J. Release and action of epidermal growth facor on gastric secretion in humans. Scand J Gastroenterol 1989a;24:485-92.

2. Konturek JW, Bielanski W, Konturek SJ, Bogdal JO, Oleksy J. Distribution and release of epidermal growth factor in man. Gut 1989b;30:1194-200.

3. Abe S, Sasano H, Katoh K, Ohara S, Arikawa T, Noguchi T, et al. Immunohistochemical studies on EGF family growth factors in normal and ulcerated human gastric mucosa. Dig Dis Sci 1997;42:1199-209.

4. Venturi S, Venturi M. Iodine in evolution of salivary glands and in oral health. Nutr Health 2009;20:119-34.

5. Polk WH Jr, Dempsey PJ, Russell WE, Brown PI, Beauchamp RD, Barnard JA, et al. Increased production of transforming growth factor alpha following acute gastric injury. Gastroenterology 1992;102:1467-74.

6. Mori S, Morishita Y, Sakai K, Kurimoto S, Okamoto M, Kawamoto T, et al. Electron microscopic evidence for epidermal growth factor receptor (EGF-R)-like immunoreactivity associated with the basolateral surface of gastric parietal cells. Acta Pathol Jpn 1987;37:1909-17.

7. Kilpi A, Bergroth V, Konttinen YT, Maury CP, Reitamo S, Wegelius O. Lymphocyte infiltrations of the gastric mucosa in Sjögren's syndrome. An immunoperoxidase study using monoclonal antibodies in the avidin-biotin-peroxidase method. Arthritis Rheum 1983;26:1196-200.

8. Pokorny G, Karácsony G, Lonovics J, Hudák J, Németh J, Varró V. Types of atrophic gastritis in patients with primary Sjögren's syndrome. Ann Rheum Dis 1991;50:97-100.

9. Buchanan WW, Cox AG, Harden RM, Glen AI, Anderson JR, Gray KG. Gastric studies in sjogren's syndrome. Gut 1966;7:351-4.

10. Karlsson FA, Burman P, Lööf L, Mårdh S. Major parietal cell antigen in autoimmune gastritis with pernicious anemia is the acid-producing $\mathrm{H}+, \mathrm{K}+$-adenosine triphosphatase of the stomach. J Clin Invest 1988;81:475-9.

11. Koski H, Konttinen YT, Hietanen J, Tervo T, Malmström M. Epidermal growth factor, transforming growth factor-alpha, and epidermal growth factor receptor in labial salivary glands in Sjögren's syndrome. J Rheumatol 1997;24:1930-5.

12. Vitali C, Bombardieri S, Jonsson R, Moutsopoulos HM, Alexander EL, Carsons SE, et al. European study group on classification criteria for Sjögren's syndrome: classification criteria for Sjögren's syndrome: a revised version of the European criteria proposed by the American-European consensus group. Ann Rheum Dis 2002;61:554-8.

13. Azuma N, Katada Y, Kitano S, Sekiguchi M, Kitano M, Nishioka A, et al. Correlation between salivary epidermal growth factor levels and refractory intraoral manifestations in patients with Sjögren's syndrome. Mod Rheumatol 2014;24:626-32.

14. Dafar A, Rico P, Işık A, Jontell M, Cevik-Aras H. Quantitative detection of epidermal growth factor and interleukin- 8 in whole saliva of healthy individuals. J Immunol Methods 2014;408:46-51.

15. Alderuccio F, Sentry JW, Marshall AC, Biondo M, Toh BH. Animal models of human disease: experimental autoimmune gastritis - a model for autoimmune gastritis and pernicious anemia. Clin Immunol 2002;102:48-58. 